\title{
Commitment with the Teaching Profession: Demographical View of Teacher Educators
}

\author{
Halima Shoaib* \\ Ibrahim Khalid $^{* *}$
}

\begin{abstract}
Competent and committed teachers are demand of today's revolutionary era to increase the effectiveness of educational institutions. We live in a high tech and high demanding age. There are sudden challenges in all walks of life, including education. This study was conducted to explore the professional commitment of teachers (teacher educators) working in Govt. Colleges for Elementary Teacher Institutions in Punjab. Three hundred and twenty teacher-educators (200 males and 120 females) were selected through proportionate random sampling from the population of 540 teacher educators. To collect data a questionnaire, Professional Commitment Questionnaire for teacher educators (PCQ-TE) was developed. The descriptive and inferential statistics i.e. t-test and ANOVA were applied for data analysis. The results revealed that the commitment towards the teaching profession increases with the increase of experience. Female teachers were more committed as compared to male teachers. Keeping in view the findings of the study, it was recommended that the social and financial status of male teachers' educators should be enhanced for increasing their commitment level. There should be proper provision of resources and training regarding professional development of rural teachers.
\end{abstract}

Keywords: Commitment, teacher-educators, professional commitment

\footnotetext{
* PhD Scholar Division of Education, University of Education, Lahore, Email: halimashoaibraja@gmail.com

** Ex-Dean, Faculty of Education, Ali Institute of Education, Lahore, Pakistan. Email: dmik44@gmail.com
} 


\section{Introduction}

Teaching in today's world is an indicator that shows how advanced a country is. Teachers across the globe prepare the future generations and uplift economy. But the dilemma with today's teaching is teachers' lack of commitment. Only motivated, committed teachers should run the education sector. The gap created due to the induction of non-committed teacher's results in the decline of education system. This defect can be rectified with the help of teachers' educators. Our country lies far behind in teachers' training issue. Actually rarely a study has been conducted on the low-commitment issue of teachers trainers' themselves. A few studies were conducted but that merely focused on secondary school and college teachers. Sadly no studies were conducted on professional commitment of teachers' educators.

Teacher's commitment is a key element in education process (Crosswell, 2006). Professional commitment lies in accepting aims of the profession with full efforts resulting in strong desire to participate in job (Ferris, 2001). Commitment is acceptance of the profession with its pros and cons. Commitment is a strong desire, participation with devotion and loyalty towards the task. It is an inborn psychological inclination for the job. Our society needs well equipped modern day teachers with pedagogical skills. This is relevant and was highlighted in Pakistani context. This is mentioned in National Education Policy (1998-2010),

"Teachers lack commitment and motivation when young men

just have teaching as a last choice for them. This is more true about male teachers than female teachers" (p. 47).

How can we resolve the commitment issue is an important task at hand? Instead of blaming teachers for lacking commitment we can discuss it in other context. Pre-service teacher education is a must in order to change the system, so importance of pre-service education programme cannot be underestimated. Only trained teachers can usher in and inculcate Pakistan's tomorrow generation a bright and promising future. Well educated and committed teacher educators can help a lot to prepare future teachers so that they may provide quality education resulting in creating a learning society, here lies the importance of professional commitment of teachers. Keeping in view all this, it is the need of the time to conduct studies to access the professional commitment of teachers in teachers' education institutions. Till date nothing like research in this area has been conducted in Pakistan.

The Directorate of Staff Development (DSD) is providing valuable services in the field of teachers training since last 50 years. Some 
administrative changes were brought in 2006. GCETs were given under the administrative control of DSD to better organize and coordinate professional development activities in the province, ensure synergy between pre and inservice teacher education and ensure efficient service delivery. Our study is focused on 33 government colleges for elementary teachers that are providing pre-service teacher education across 23 districts in Punjab. As we know that in these 33 colleges, teachers are prepared and developed professionally. So it is necessary to assess the level of professional commitment of teachers that are preparing the teachers of next generation. It is a thoughtful question that if the teachers who are working in teacher training institutions are not professionally committed how they can perform their duties well for preparing next teacher's generation.

\section{Literature Review}

It is a common observation that students get emotionally and psychologically attached to their teachers. Their affiliation lasts long. Students idealize, imitate and assimilate the qualities of their teachers. A teacher teaches all other professions. Teaching itself is a process of learning. A teacher is a seeker of knowledge till his/her death day. Their behavior everywhere in every situation is a form of teaching. Every country needs quality teachers for its progress. Teachers are nation builders. A teacher himself should be updated with latest techniques and skills. Taylor and John (2002) are of the view that professional teachers must have skills, mechanism to use skills, wisdom and judgment as well. The use of term "profession" has its origins in European language since $18^{\text {th }}$ century. It is synonymous with the term occupation. The word profession and occupation are interchangeably revealed in such phrases as professional, technical and occupational. Professionals are persons who are self motivated, capable and competent (Evans, 2008). The teacher's professional commitment can directly be related to research studies performed in 1970's into institutional commitment. Unfortunately professional commitment aspect lacks research attention (Beri \& Beri, 2016), though it has serious consequences for an individual's permanent stay in any profession. Occupational commitment is a process that may be viewed as the positive feelings of an individual towards his/ her profession, and the eagerness to remain in the same occupation. However, occupational commitment is related to continuous and normative professional commitments (Meyer, 1993). Therefore, it becomes compulsory to have deep insight into teacher's 
commitment because it is closely related to the quality of teaching learning process. Commitment consists of various factors.

"Various factors influence professional commitment, which are changes in social dynamic of classroom teaching, poor leadership, challenges to long notions of professional identity, working conditions and well-being as well as generational and ageing factors"(Day \& Gu, 2009, p.454).

According to Chughatai and Zafar, (2006) professional commitment is based on sense of belonging, hard work and full contribution of the employee. Professional commitment is a bond of the individual to the profession (Evans, 2008). Some Pakistanis researchers like Anwer, Tahir and Batool (2012) opined that professional commitment among government sector employees be measured with certain variables like job satisfaction, motivation of work and attainment of goals. Teacher professional commitment is relevant factor to determine and influence organizational outcomes. It is vital for quality, productivity and performance (Henkin \& Holliman, 2009). If the staff is committed, we can predict a better future of organization. Student achievement can be enhanced through it. The teacher educator is responsible to provide and himself receive a healthy academic and vibrant atmosphere in the training colleges. Sood and Anand, (2010) defines that good environment and attractive salaries enhance teacher commitment towards profession. High level of professional commitment can be maintained if employees plan their work and apply professional decisions in a fair way (Rizvi \& Elliot, 2005).

\section{Domains of Professional Commitment}

It is important to know the factors on which professional commitment depends. According to Meyer (1993), professional commitment comprises of three components. These are affective professional commitment, continuance professional commitment and normative professional commitment. Afterwards these three components were studied variously (Suliman \& Iles, 2000).

\section{Affective Professional Commitment}

Affective professional commitment is the emotional, psychological attachment of the person with the organization. It is a sort of good participational feelings and pleasure derived out of job; it gives contentment with status to be a teacher (Ibrahim \& Iqbal, 2015). 


\section{Normative Professional Commitment}

It is the sense of obligation for an organization. It is the parameter of an individual's moral stature and his sense of responsibility. Institutional support, justice, role clarity, and job satisfaction also play part. Meyer, Stanley, Herscovitch and Tpoplnysky (2002) state that it is their moral obligation to stay in the profession forever.

\section{Continuous Professional Commitment}

Employee's needs determine his commitment. These are financial demands that pressurize the employee to remain with organization. Financial perks, seniority, incentives are the factors that complement the bond between the employee and the organization. Suliman and Iles (2000) explain that teachers' financial conditions do not permit them to leave job because they have responsibilities of their family.

\section{Commitment of Teachers with Work Group}

Friendly environment and relationship with colleagues is good for achievement of institutional goals. Teachers' commitment to work group is a main indicator that tells to give appropriate value in one's friends, outside the school. Teachers spend time with each other in institutions at break time. Teachers' relationships with working groups influence their commitment. According to Celep (2001), commitment to teaching work gets first priority, second priority is to work group, teaching occupation is at third number and commitment to school at the last(Day \& Gu, 2009). A teacher who is involved with his/her colleagues, peers, friends share knowledge beliefs and goals of teaching, brings positive result.

\section{Collegial Participative Leadership and Teacher's Professional Commitment}

A good leader is always task oriented. Ross and Gray (2006) reinforced the link between leadership and commitment with their study. Good principals make every possible effort to guide, instruct, evaluate, assess and inspire the teachers. Teachers at the start of their career have high morals and ready to be more committed if they are coaxed and guided and applauded by the principals. It boosts their morale, self esteem and confidence (Huang, 2011). Supportive principals are source 
of professional commitment. These principals believe in proper feedback, encouragement and clear targets (Taylor \& John, 2002).

Many researchers have conducted research regarding demographic variables and professional commitment. Here some important researches have explained about some important factors of professional commitment. One factor is age. Professional commitment increases with age. Experts like Anwer, Tahir, and Batool (2012) show a strong link between age and professional commitment. There is strong correlation between age and commitment. Researches validate this correlation (Solangi, Qaisrani \& Mughal, 2015).

Gender is also an important factor in professional commitment studies. Women show more commitment than men (Bogler \& Somech, 2004). Views differ about which gender is more committed. Few researchers like Beri and Beri (2016) disagree with the present finding. They say that male teachers are more committed than female teachers. However, Kannan and Pillai (2008) found that with the changes in time women have got other career options. This was not the case in the past, but now it is showing. Researchers, Usha and Sasikumar (2007) argue that job security also affects commitment to work stronger for professional females. In his study Sood and Anand (2010) observed that male worker gives priority to money while female gives priority to work itself.

Locality is also a factor that is also important in professional commitment. Students in small cities are less satisfied with the commitment of their GCET's teachers as compared to teachers at big cities. In big cities teachers have better opportunities and chances of learning. In big cities teachers have other learning options as well. (Saeed, Afzal \& Mahmood, 2008).

Experience has no alternative. It is the one ingredient that increases commitment. With experience one becomes proficient, efficient and viable. One feels pleasure and leisure in work. Every boring task becomes very interesting with time (Rizvi \& Elliot, 2005). Chuan, (2010) studied three groups of teachers one group had experience of five years; second group had experience of 10-20 years. Third group had the experience of over 25 years. Significant difference of commitment was observed in the first and third group. Sylvester, (2010) reached at the conclusion that the teaching experience was a good evident factor. So that more experienced teachers bring good result.

The education of teachers themselves is essential for their development and growth. The selected, efficient, committed, devoted teachers should train the teachers of future. While teacher educators play a vital role but they themselves are the most neglected entity. Commitment of teacher educators is of prime importance for better commitment of prospective teachers. 


\section{Objectives of the Study}

The objectives of the study were to:

1. Determine the professional commitment level of teachers working in Govt. Colleges for Elementary Teacher Institution in Punjab.

2. Identify the difference in the professional commitment of teachers with respect to demographic variables.

\section{Hypotheses of the Study}

Ho1: All the teacher educators working in Govt. Colleges for Elementary Teacher institutions of Punjab has same level of professional commitment.

Ho2: There is no significant difference of professional commitment of male and female teacher educators working in Govt. Colleges for Elementary Teacher institutions of Punjab.

Ho3: There is no significant difference of professional commitment of urban and rural teacher educators working in Govt. Colleges for Elementary Teacher institutions of Punjab.

Ho4: There is no significant difference of professional commitment of teacher educators having different experience level working in Govt. Colleges for Elementary Teacher institutions of Punjab.

\section{Methodology}

As the present study was designed to explore the level of professional commitment of teacher educators who are working at Govt. Colleges for Elementary Teachers (GCETs) in province of Punjab. Researchers decided to know the views of teacher educators about professional commitment therefore; a survey type research methodology was considered the best to investigate the problem.

\section{Population and Sample}

Population of the study consisted of all the teacher-educators of Government Colleges for Elementary Teachers (GCETs) in the province of the Punjab. There were 33 Government colleges for elementary teachers (GCETs) in the province of Punjab that comprised the population of the study. There were 540 teacher-educators (340 males and 200 females) in these 33 GCETs. In this way 320 (200 male and 120 
female) teacher educators were selected as sample of the study through proportionate random sampling technique.

\section{Instrumentation}

Professional Commitment Questionnaire (PCQ) comprised of two parts. The first part of questionnaire was about the demographic information of teacher-educators, like gender, locality and teaching experience. Second part of the questionnaire comprised statements about the domains of professional commitment. The second part of the questionnaire was comprised of five-point rating scale. The questionnaire's sub-categories were: Commitment to Teaching Profession, Affective Professional Commitment, Normative Professional Commitment, Continuity of Professional Commitment, Commitment to Work Group and Collegial Participative Leadership. Questionnaire was developed by the researcher herself in the light of prescribed indicators and literature review keeping in view the objectives and hypotheses of the study. The researcher developed and finalized questionnaires with the help of expert's opinion.

\section{Validity and Reliability of Instrument}

A group of experts were selected from educationists and researchers to maintain the content, construct and face validity of the instrument. To check the group matching validity of all the statements of instruments, factor analysis was done. According to the results of factor analysis and value judgment of the researcher the instrument was modified and improved.

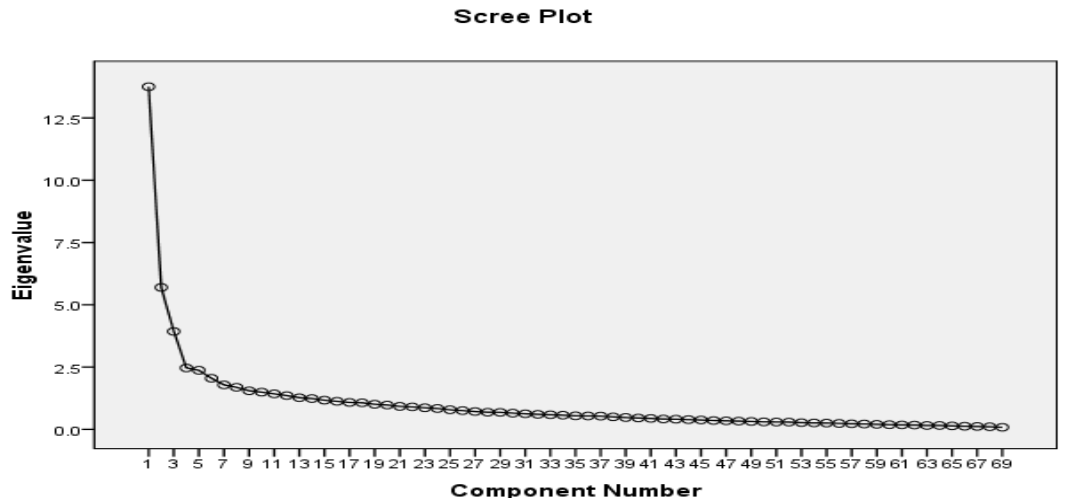

Figure 1: Scree plot showing number of possible subcategories in teacher educators' questionnaire 
Pilot testing was conducted to know the preliminary results and to determine the reliability of the instruments. Instruments were pilot tested on small scale. For pilot testing 3 GCETs were selected conveniently. These GCETs were (i) GCET Kot Lakh Pat Lahore, (ii) GCET D.G. Khan (M), (iii) GCET Sargodha. From these three GCETs there were six male teacher-educators and four female teacher-educators were selected for pilot testing. Cronbanch's alpha was used to check the reliability of instrument. The reliability of teacher educators' questionnaire was .92 .

\section{Data Analysis and Results}

Keeping in view the nature of hypotheses and data, appropriate tests were applied. To address the hypotheses, collected data was analyzed by using descriptive andinferential statistics i.e. t-test and ANOVA tests were used to draw results. Detail of data analysis and results generated from analysis are given in the tables below:

Table 1

Professional Commitment Level of GCETs Teachers' Educators

\begin{tabular}{|c|c|c|c|c|c|c|c|c|c|c|}
\hline \multirow[t]{3}{*}{ Respondents } & \multicolumn{10}{|c|}{ Commitment Level } \\
\hline & \multicolumn{2}{|c|}{$\underline{\text { Low }}$} & \multicolumn{2}{|c|}{ Moderate } & \multicolumn{2}{|c|}{ High } & \multicolumn{2}{|c|}{ Very High } & \multicolumn{2}{|l|}{ Total } \\
\hline & $\mathrm{N}$ & $(\%)$ & $\mathrm{N}$ & $(\%)$ & $\mathrm{N}$ & $(\%)$ & $\mathrm{N}$ & $(\%)$ & $\mathrm{N}$ & $\%$ \\
\hline Teacher's Rating & 5 & 1.7 & 11 & 3.8 & 137 & 47.6 & 135 & 46.9 & 288 & 100.0 \\
\hline
\end{tabular}

Table 1 shows the results related to commitment level of teacher educators in the Punjab province. Majority of teachers' commitment level falls between high and very high level. These results depict very supportive picture regarding commitment level of teacher educators. Table 2 shows another aspect of professional commitment level of teacher educators i.e. commitment level regarding different main aspects for academic efficiency.

Table 2

Commitment Level of Teachers According to Teachers' Rating

\begin{tabular}{lllll}
\hline Domains & $\underline{M}$ & $\underline{S D}$ & $\underline{\%}$ & $\underline{\text { RANK }}$ \\
\hline Commitment to Teaching Profession & 4.19 & .56 & 83.75 & 2 \\
Affective Professional Commitment & 4.11 & .56 & 82.19 & 3 \\
Normative Professional Commitment & 4.02 & .58 & 80.32 & 5 \\
Continuous Professional Commitment & 3.31 & .76 & 66.15 & 6 \\
Commitment to Teaching Work & 4.22 & .43 & 84.39 & 1 \\
Collegial Participative Leadership & 4.09 & .50 & 81.74 & 4 \\
\hline
\end{tabular}


Table 2 shows that commitment to teaching work domain is at first rank $(M=4.22, S D=0.43)$ which means teachers of GCETs are committed and fair with their teaching profession and practical aspects of this profession. In the same way, commitment to the teaching profession is at the second level with mean value $\mathrm{M}=4.19$ and $\mathrm{SD}=0.56$. This second level also shows that teachers were committed to the teaching profession. Continuous professional commitment is at the last stage in the ranking of different domains of professional commitment of teachers. Continuous professional commitment means that teachers are bound to stay in the profession due to some financial problems. This last and least level show that they were not bound to stay in this job due to some problems but they were interested to stay in the job. A graphical description and comparison of all domains is given in the graph 1 .

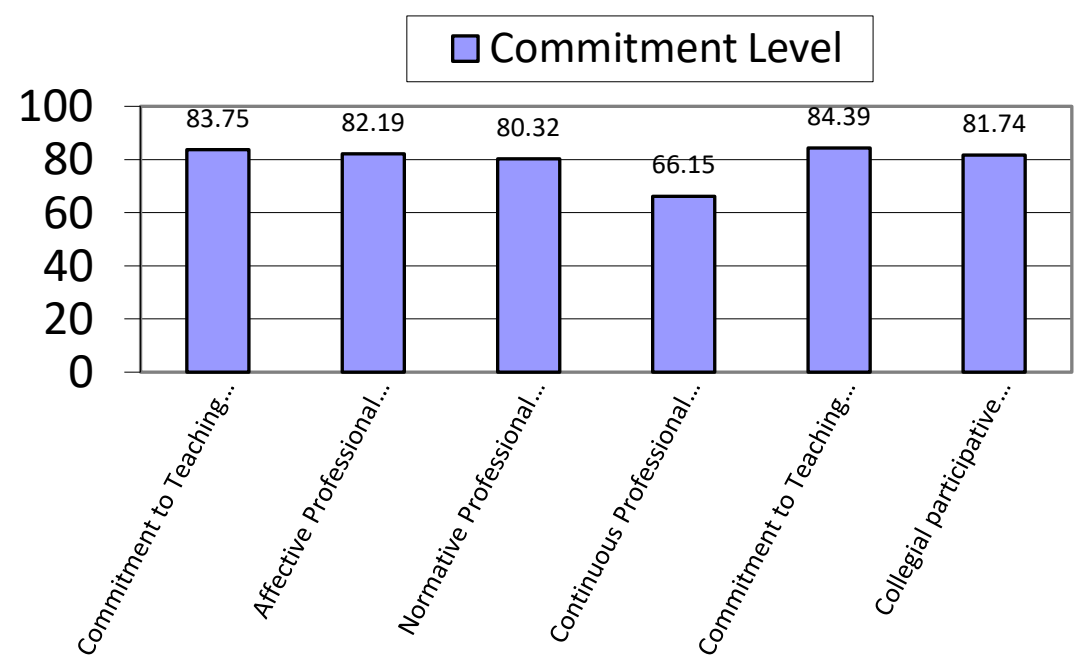

Figure 1: Teachers' Self-Appraisal about Different Domains of Commitment Level 
Table 3

Mean Scores of Male and Female Teachers about Teachers' Commitment

\begin{tabular}{|c|c|c|c|c|c|}
\hline \multirow[t]{2}{*}{ Domain } & \multicolumn{2}{|c|}{$\begin{array}{c}\text { Male } \\
\underline{N=180} \\
\underline{4}\end{array}$} & \multicolumn{2}{|c|}{$\begin{array}{l}\text { Female } \\
\underline{N=108}\end{array}$} & \multirow[b]{2}{*}{$\underline{\mathrm{t}}$} \\
\hline & Mean & $\underline{S D}$ & Mean & $\underline{S D}$ & \\
\hline Commitment to Teaching Profession & 4.06 & 0.59 & 4.40 & 0.43 & $-5.28 * *$ \\
\hline Affective Professional Commitment & 3.98 & 0.57 & 4.32 & 0.47 & $-5.22 * *$ \\
\hline Normative Professional Commitment & 3.89 & 0.60 & 4.23 & 0.48 & $-4.95 * *$ \\
\hline Continuous Profession Commitment & 3.26 & 0.75 & 3.39 & 0.76 & -1.38 \\
\hline Commitment to Work Group & 4.38 & 0.55 & 4.00 & 0.39 & $6.23 * *$ \\
\hline Collegial Participative Leadership & 3.96 & 0.48 & 4.30 & 0.45 & $-6.00 * *$ \\
\hline Total & 3.91 & 0.31 & 4.23 & 0.31 & $-8.46 * *$ \\
\hline
\end{tabular}

$* * \mathrm{p}<0.01$

Table 3 shows the comparison between male and female teachers about their commitment in different domains of commitment. The results show that there is significant difference in male teachers and female teachers $(t=$ -8.46, $p=0.00$ ) on Professional commitment scale. Female teachers are highly committed to their profession in all domains except work group commitment. But mean values of commitment to the work group show that male teachers $(M=4.38, S D=0.55)$ have good relation with their colleague than females $(M=4.00, S D=0.39)$. On the other side, there is no significant difference in continuous professional commitment domain.

Table 4

Mean Scores of Rural and Urban Teachers about Teachers' Commitment

\begin{tabular}{|c|c|c|c|c|c|}
\hline \multirow[b]{2}{*}{ Domain } & \multicolumn{2}{|c|}{$\frac{\text { Rural Teachers }}{\underline{\mathrm{N}=58}}$} & \multicolumn{2}{|c|}{$\begin{array}{l}\frac{\text { Urban }}{\text { Teachers }} \\
\underline{\mathrm{N}=230} \\
\end{array}$} & \multirow[b]{2}{*}{$\underline{\mathrm{t}}$} \\
\hline & Mean & $\underline{S D}$ & Mean & $\underline{S D}$ & \\
\hline Commitment to Teaching Profession & 3.87 & 0.65 & 4.26 & 0.50 & $-4.92 * *$ \\
\hline Affective Professional Commitment & 3.76 & 0.69 & 4.20 & 0.49 & $-5.44 * *$ \\
\hline Normative Professional Commitment & 3.72 & 0.71 & 4.09 & 0.52 & $-4.44 * *$ \\
\hline Continuous Professional Commitment & 3.38 & 0.71 & 3.29 & 0.77 & 0.78 \\
\hline Commitment to Work Group & 4.22 & 0.71 & 4.24 & 0.47 & -0.30 \\
\hline Collegial Participative Leadership & 3.81 & 0.57 & 4.15 & 0.46 & $-4.77 * *$ \\
\hline Total & 3.79 & 0.40 & 4.09 & 0.31 & $-6.10 * *$ \\
\hline
\end{tabular}


Table 4 shows comparison between rural and urban teachers about their commitment in different domains of commitment. There is significant difference in rural and urban teachers $(t=-6.10, p<.001)$ on professional commitment scale as a whole and in all the domains of professional commitment except work group and continuous professional commitment. The difference is not significant between rural and urban teachers in continuous professional commitment $(t=0.78, p=0.435)$, but the mean values show that rural teachers $(M=3.38, S D=0.71)$ consider themselves more bound as compared to urban teachers $(M=3.29, S D=$ 0.77 ) in this teaching profession due to financial matters.

Table 5

Mean Scores of Teachers' Commitment with Different Teaching Experience

\begin{tabular}{|c|c|c|c|c|c|c|c|}
\hline & \multicolumn{2}{|c|}{$\leq 10 N=57$} & \multicolumn{2}{|c|}{$10-20 N=93$} & \multicolumn{2}{|c|}{$21-30 N=138$} & \\
\hline Commitment & Mean & $\underline{S D}$ & Mean & $\underline{S D}$ & Mean & $\underline{S D}$ & $\underline{F}$ \\
\hline $\begin{array}{l}\text { Teaching } \\
\text { Profession }\end{array}$ & 3.91 & 0.59 & 4.16 & 0.60 & 4.33 & 0.46 & $12.24 * *$ \\
\hline Affective & 3.79 & 0.56 & 4.12 & 0.56 & 4.24 & 0.51 & $14.59 * *$ \\
\hline Normative & 3.84 & 0.59 & 3.94 & 0.64 & 4.15 & 0.50 & $7.34 * *$ \\
\hline Continuous & 3.14 & 0.69 & 3.23 & 0.75 & 3.43 & 0.78 & $3.63 *$ \\
\hline Work Group & 4.11 & 0.51 & 4.21 & 0.62 & 4.32 & 0.44 & $3.30 *$ \\
\hline $\begin{array}{l}\text { Participative } \\
\text { Leadership }\end{array}$ & 3.97 & 0.53 & 4.08 & 0.45 & 4.14 & 0.52 & 2.38 \\
\hline Total & 3.85 & 0.34 & 4.00 & 0.32 & 4.12 & 0.34 & $13.89 * *$ \\
\hline
\end{tabular}

$* \mathrm{p}<0.05$ and $* * \mathrm{p}<0.01$

Table show results of ANOVA among GCET teachers having different experience to know their commitment on the professional commitment scale. According to experience, teachers were divided into three categories i.e. less than 10 years, 10 to 20 years and 21 to 30 years. Above table indicates that there was significant difference $(\mathrm{F}=13.89, p<0.001)$ among the teachers of different experiences on professional commitment scale as a whole. The results further highlight that there was significant difference in all the domains of professional commitment except collegial participative leadership. Table also depictes the picture that commitment increased with the increase of experience i.e. for $\angle 10(M=3.85, S D=0.34)$, for 10-20 $(M=$ 4.00, $S D=0.32)$ and for 21-30 $(M=4.12, S D=0.34$. 


\section{Discussion}

According to rank order as a whole commitment to work group was at first rank and commitment to teaching profession was found at the second rank. These results were also supported by a study conducted by Celep (2001). It is observed that commitment to work group is an indicator of a teacher's involvement in the profession and his liking for the job. Their loyalty towards profession is the revelation of their inner psychological liking for teaching as a job. Affective commitment domain was at the top and normative commitment domain was at second level while continuous commitment domain was at third level. Similarly, Shah, Marwan and Abualrob, (2012) quoted the highest mean values were observed for affective (desire-based) component as compared to continuance and normative commitment. The results of the descriptive analysis showed that teachers' educators in Pakistan feel proud to be in the teaching profession and do not feel any stress in this profession.

Overall view depicted that female teachers' educators commitment level was higher as compared to male teacher educators. Bari and Bari, (2016) also reported that female teachers had more positive attitude towards teaching profession as compared to male teachers. Previous researches have also supported that commitment to teaching were higher for women than men (Solangi, Qaisrani\& Mughal, 2015; Shukla, 2009). The reason for this might be that generally females had more loving attitude towards children and were more inclined to adopt teaching profession as compared to males. Females are more flexible, pragmatic and down to the earth, close to human nature. They are creative, experimental and kind natured. They have more altruistic and have intrinsic reasons to join teaching profession. But the results were contrasted in a study conducted by Goswami and Choudhury (2016) who indicated that a large proportion of male teachers had higher professional involvement as compared to female teachers.

It was found that urban teacher educators were more committed than rural teacher educators in all domains of professional commitment. Ibrahim and Iqbal (2015) also predicted that urban teachers had relatively better job performance than their rural counterparts. This may be due to the fact that urban teachers had more chances, physical facilities like internet, institutions, transportation etc. and therefore, had more opportunities of growth and professional development as compared to the rural locality teachers.

It was also found that highly experienced teachers have high commitment while, commitment of less experienced to their profession 
was not up to the mark. Atak and Erturgut (2010) also found that teachers' age and teaching experience in any institution relate to the professional commitment. These results were also supported by Sood and Anand (2010).

\section{Recommendations}

In a male dominated society in Pakistan, males are mainly responsible for handling financial responsibilities of their dependents, for which sufficient income is required. Policy makers should focus on enhancing social and financial status of male teachers so that they take pride in teaching profession and work with devotion and interest. Similarly, qualification and experience plays effective role on professional commitment of teacher educators, therefore, during selection process of teachers distribution of marks should be based on qualification and experience properly. Furthermore, experience should be given top priority in recruitment process of teachers for better performance level.

Knowledge and skill are the two basic pillars for quality education. Knowledge is pre-service qualification while training is the responsibility of the department. Therefore, proper resources and latest training techniques should be provided to all the teacher educators particularly those working in rural areas with their urban counter parts to enhance professional commitment of teacher educators. Seminars and programs should be arranged for awareness about importance of professional commitment. This may also be a better motive for the improvement of professional commitment among teacher educators. 


\section{References}

Anwer, M. , Tahir, T., \& Batool , S. (2012). Professional role of teachers in government colleges and higher secondary schools for F.Sc. programme in Punjab: Acomparative study. Social Sciences and Humanities, 3(3), 265-274.

Atak, M., \& Erturgut, R. (2010). An empirical analysis on the relation between learning organization and organizational commitment. Procedia Social and Behavioral Sciences, 2. 3472-3476.

Beri, N., \& Beri, A. (2016). Professional commitment of teacher educators in relation towork motivation. International Journal of Research in Humanities, Arts and Literature, 4(1), 45-52.

Bogler, R., \& Somech, A. (2004). Influence of teacher empowerment on teachers organizational commitment, professional commitment and organizational citizenship behavior in schools. Teaching and Teacher Education, 20, 277-289.

Celep, C. (2001). Teachers' organizational commitment in educational organizations. National Forum of Teacher Education Journal, $10(3), 220-229$.

Chuan, L. C. (2010). A follow up study of commitment and job satisfaction of teacher educators. Journal of Penyelidikan, 9, 65-81.

Chughatai, A. A., \& Zafar, S. (2006). Antecedents and consequences of organizational commitment among Pakistani university teachers. Journal of Applied H.R.M. Research, 11(1) 39-54.

Crosswell, L. (2006). Understanding teacher commitment in times of change. Unpublished doctoral dissertation Queensland University of technology. Retrieved May 26, 2007 from http://adt.Caul.Edu.au

Day, C., \& Gu, Q. (2009). Veteran teachers: Commitment, resilience and quality retention. Journal of Teachers and Teaching: Theory and Practice, 15(4), 441-457. 
Evans, L. (2008). Professionalism, professionality and the development of education professionals. British Journal of Educational Studies, 56(1), 20-38.

Ferris, K. R. (2001). Organizational commitment and performance in a professional accounting firm. Organizations and Society, 6(4), 317-328.

Goswami,D., \& Choudhury, G. (2016). A study on professional commitment of teacher educators in relation to institutional climate. The International Journal of Humanities \& Social Studies, 4(5), 177-180.

Government of Pakistan. (1998-2010). National education policy. Islamabad: Ministry of Education.

Henkin, A. B.\& S. L. Holliman (2009). Urban teacher commitment exploring associations with organizational conict, support for innovation, and participation. Urban Education, 44, 160-180.

Huang, T. M. (2011). The relationship between headmasters' leadership behavior and teachers' commitment in primary schools in the district of sarikei, Sarawak. Social and Behavioral Sciences, 29, 1725-1732.

Ibrahim, M., \& Iqbal, M. (2015). Teachers' perception of professional commitment (affective, continuance and normative commitment) to teaching profession. European Journal of Business and Management, 7(10),64-80.

Kannan, R., \& Pillai, P. M. S. (2008). An examination on the professional commitment of engineering college teachers. Journal of International Business Management, 2(6), 218-224.

Meyer, J. P. (1993). Commitments to organizations and occupations: Extension and test of a three components models. Journal of Applied Psychology, 78, 538-555.

Meyer, J. P., Stanley, D. J., Herscovitch, L., \&Topolnytsky, L. (2002). Affective, continuance, and normative commitment to the organization: A meta-analysis of antecedents, correlates, and consequences. Journal of Vocational Behavior, 61(1), 20-52 
Rizvi, M., \& Elliot, B. (2005). Teachers' perceptions of their professionalism in government primary schools in Karachi, Pakistan. Asia-Pacific Journal of Teacher Education,33(1), 35-52.

Ross, A. J., \& Gray, P. (2006). Transformational leadership and teacher commitment to organizational values: The mediating effects of collective teachers' efficacy. Journal of School Effectiveness and School Improvement, 17(2), 179-199.

Saeed, M., Afzal, M. T., \& Mahmood, T. (2008). Assessing teachers' performance at higher education level in Pakistan. Journal of Research and Reflections in Education, 2(1), 13-32.

Shah, M., Marwan, M. A., \& Abualrob, (2012) Teacher collegiality and teacher professional commitment in public secondary schools in Islamabad, Pakistan. Social and Behavioral Sciences, 46, 950-954.

Shukla, S. (2009). Teaching competency, Professional Commitment and jobsatisfaction. Retrieved from http://www.Illusion.instablogs.com

Solangi, M. G., Qaisrani, N., \& Mughal, S. (2015) .A study of factors influencing public sector secondary school teachers' job satisfaction. International Journal of Academic Research in Business and Social Sciences.5(5), 262-275.

Sood, V., \& Anand, A. (2010). Professional commitment among B.Ed. teacher educators of Himachal Pradesh. 1-5. Retrieved from http://www.ejournal.aiaer.net/vol122110/7.pdf.

Suliman, A., \& Iles, P. (2000). Is continuance commitment beneficial to organizations? Commitment-performance relationship: A new look. Journal of Managerial Psychology, 15(5), 407-42.

Sylvester, J. M. (2010). Attitude towards teaching profession and job satisfaction of teacher educators. Edutracks, 9(8), 36-38.

Taylor, J. W., \& John, M. C. (2002). Leadership approach, school climate, and teacher commitment: A Philippine perspective. Christian Education Journal, 6(1), 83110. 
Usha, P. \& Sasikumar, P. (2007). Teachers' commitment and teachers'selfconcept as predictors of job satisfaction. Edutracks 6 (1) 26-29.

\section{Citation of this Article:}

Shoaib, H., \& Khalid, I. (2017). Commitment with the teaching profession: demographical view of teacher. Pakistan Journal of Education, 34(2), 19-36.

Received on: December 01, 2016

Revised on: October 31,2017

Accepted on: November 15, 2017 